\title{
Fra syndfloden til æstetikken
}

I sin afskedsforelæsning, "Après le déluge", fortæller Niels Peter Lemche livfuldt om den gammeltestamentlige Københavnerskoles tilblivelse og udvikling frem til i dag, hvor dens sidste Gründer er gået af. Når den historisk-kritiske metode gennemføres radikalt sammen med arkæologi, sociologi og etnografi, lander den gammeltestamentlige forskning ifølge Lemche med en serie af fortællinger, der har været (og er) identitetsskabende for jøder, men som samtidig rummer filosofiske pointer, der ligner den græske hellenisme. Som en Noahs ark efter syndfloden, fristes man til at sige. GT hører derfor naturligt med til den tidlige kristendoms fælles kulturelle erindring.

Filosoffen Johannes Steenbuch forsvarede d. 15. maj 2014 en ph.d.afhandling med teologisk tema og tyngde, Doing the Unthinkable: Theology and Moral Epistemology in Three Early Christian Thinkers om Ignatius, Clemens og Gregor af Nyssa. I sin artikel gør Steenbuch gældende, at eftersom fornuften ikke kan tænke Gud i forlængelse af tid-rumlige kategorier, skal Gregors tale om Guds u-endelighed næppe forstås som et positivt gudsbegreb, men snarere som en benægtelse af Guds endelighed. Gregors filosofiske teologi indebærer, at etik og livsførelse står i centrum af hans teologi - ikke metafysikken i sig selv, sådan som andre fortolkere har ment.

Jonas Adelin Jørgensen gennemgår minutiøst de forskellige faser i Ernst Troeltsch's religionsteologi, særligt vanskeligheden med at fastholde kristendommens universalitet. Som historist mente Troeltsch, at al erkendelse må begynde i historiens immanente netværker. Men hvordan så undgå en almen relativisme, der gør alle katte grå? Troeltsch gjorde forsøget. Men lykkes han? Ét af den lutherske teologis bolværker mod relativismen er det ydre ord. Men så snart evangeliet skal kommunikeres til nogen, vender kontekst og relativitet tilbage. Bent Flemming Nielsen gennemgår to nyere tyske forsøg på at klargøre den praktiske teologis status. Mens Fritz Lienhard opterer for en hermeneutisk grundlæggelse, gør Alexander Deeg liturgien gældende som udtryk for en æstetisk præsenskultur, der er mere grundlæggende end den mere flydende tydningskultur. Lur mig, om ikke Bent Flemming Nielsen følger Deeg!

Med dette nummer takker jeg af efter 22 rigtigt gode år i redaktionen. Jeg byder Bo Kristian Holm velkommen som ny hovedredaktør, og Jesper Høgenhaven og Johanne Stubbe Teglbjærg Kristensen som nye redaktionsmedlemmer til afløsning af Pernille Carstens og undertegnede. Crescat et vivat! 